\title{
妊婦・裖婦の乳がん検診における血清乳癌腫瘍マーカーの位置づけ 乳癌治療後娃娠例での検討
}

\author{
森 久仁子1) 土橋 一慶2,3) 植木 實1) 冲永 功太 ${ }^{31}$ \\ 大阪医科大学附属病院産婦人科1) \\ 千川産婦人科医院 ${ }^{2}$ \\ 帝京大学医学部附属病院外科 ${ }^{3}$
}

\begin{abstract}
妊婦・裖婦に乳癌が合併した妊娠関連乳癌は，臨床期別分類にしたがった進行度と同様 の予後であると考えられている。しかし，妊婦・裖婦に対する系統的乳がん検診法が確立 されていない現状では，進行乳癌の状態で発見されることが多い。現在まで妊娠初期の視 ・触診法に超音波検查を併用する検診法が報告されているが，妊娠性変化による偽陽性が 多いとされている。今回, 乳癌治療後の経過観察中に妊娠した症例で，妊娠・産裖期を通 じて継時的に腫瘍マーカーを測定し得た症例を経験したので，腫瘍マーカーを妊婦・裖婦 の乳がん検診に併用する際の留意点について考察した。検討した血清腫瘍マーカーはCA 15-3と NCC-ST-439である。CA15-3は妊娠中期〜後期に上昇を認め，NCC-ST-439は妊 娠初期に一過性に上昇を認めたが，いずれも産裖 4 ケ月で非妊娠時の值に回復した。

以上の症例から，生理的な妊娠性変化により腫瘍マーカーが変動するので，妊娠時に乳 癌腫瘍マーカーを追加検査するときには妊娠時期を考慮して判定しなければならないと思 われた。
\end{abstract}

Key words : 妊娠関連乳癌, 乳がん検診法, 腫瘍マーカー, CA15-3, NCC-ST-439

\section{緒 言}

妊婦・裖婦に乳癌が合併した妊娠関連乳癌は, 臨床期別分類にしたがった進行度と同様の予後で あると考えられている ${ }^{1)}$ 。しかし，妊婦・裖婦に 対する系統的乳がん検診法が確立されていない現 状では，自験例を含めて進行乳癌の状態で発見さ れることが多いと思われる2。

妊婦・裖婦における乳がん検診方法として，1) 視・触診法，2)超音波検査，3) マンモグラフ イ，4) 血清乳癌腫瘍マーカー測定（以下，腫瘍マ 一カー)などが考えられるが，経時的に進行・変 化する妊娠・産裖現象という特殊な環境下では,

\section{別冊請求先： $=569-8686$ 高槻市大学町 2-7 大阪医} 科大学附属病院産婦人科森 久仁子 E-mail address : kuniko-mr@r9. dion.ne.jp
胎児への影響も考慮して諸検査を制限せざるを得 ない。妊婦，裖婦に対するマンモグラフィの有用 性は，高密度乳腺のため閉経後女性よりも著しく 低い。一方，妊娠初期の視・触診法に超音波検查 を併用する検診法については，われわれの検討か ら乳房における異常の早期発見がある程度可能で あった2,3)。そこで，妊娠性変化による偽陽性率 (false positive)が高いことは検診の立場からする とさらに考慮しなければならない問題である。腫 瘍マーカー (CA15-3, NCC-ST-439など)に関して は, その併用の可否はもとより, 妊娠から産裖現 象における值の変動についてもまったく検討され ていない。

今回, 乳癌治療後の経過観察中に妊娠した症例 で，妊娠・産裖期を通じて経時的に腫瘍マーカー を測定し得た症例を経験したので，腫瘍マーカー を妊婦・裖婦乳がん検診に併用する際の留意点に 
表 1. 乳癌治療後に妊娠した 4 症例

\begin{tabular}{c|c|c|c|c|c|c|c|c}
\hline 症例 & 年齢 & stage & 術式 & リンパ節転移 & 病理組織 & ER & PR & 術後治療 \\
\hline 1 & 37 & $\mathrm{I}$ & $\mathrm{Bt}+\mathrm{Ax}$ & $(-)$ & 乳管癌 & $(+)$ & $(+)$ & $(-)$ \\
2 & 38 & 0 & $\mathrm{Tm}$ & $(-)$ & 非浸潤性乳管癌 & 不明 & 不明 & 乳頭部再発 $\rightarrow 5 \mathrm{FU}$ 内服 \\
3 & 40 & II A & $\mathrm{Bt}+\mathrm{Ax}$ & $(-)$ & 充実腺管癌 & $(-)$ & $(-)$ & $(-)$ \\
4 & 27 & $\mathrm{I}$ & $\mathrm{Bq}+\mathrm{Ax}$ & $(-)$ & 硬癌 & $(-)$ & $(-)$ & 放射線治療 \\
\hline
\end{tabular}

ついて，文献的考察を含めて検討したので報告す る。

\section{1. 対象と経過}

初回治療後に妊娠し，妊娠・産裖期間を通じて 再発を認めなかった乳癌 4 例を対象とした。平均 年齢は 34.6 歳であった(表 1)。当院乳腺外来受診 者で，同年齢層との比較のために CA15-3, NCC -ST-439を測定した症例を対照群とした $(\mathrm{CA} 15-3$ 測定；20例, 平均年齢34.5歳, NCC-ST-439測定 ; 11例，平均年齢33.1歳)。なお，今回測定したキ ットの基準值は $\mathrm{CA} 15-3: 28 \mathrm{U} / \mathrm{m} l$ 以下 $(\mathrm{ACS}$ 180)，NCC-ST-439:7.0U/ml 以下(ラナエンザ イム439)で，用いた対照もいずれも基準值内であ
つた ${ }^{4,5)}$ 。各症例における初回治療から妊娠に至る までの経過を示す。

症例 1 (37歳, 0 回経妊 0 回経産)：最大 $1.0 \times 0.5$ $\mathrm{cm}$ の多発腫瘤のため，2001年11月胸筋温存乳房 切除術を施行した(T1 N0 M0)。2001年12月17日 を最終月経として妊娠し，2002年10月 9 日正常分 婏 (男児， $3,512 \mathrm{~g}$ ) となった。産裖経過は順調で 6 カ月間授乳した。

症例 2(38歳, 1 回経妊 1 回経産)：1994年11月 に非浸潤性乳管癌のために乳房温存術を施行した が，1996年 6 月乳頭部に再発したため残存乳房切 除術とリンパ節郭清術を施行した。リンパ節転移 は認めなかったが，追加補助療法として再発後 3 年間 $5 \mathrm{FU}$ 剂を投与した。投与終了後の 2000 年11
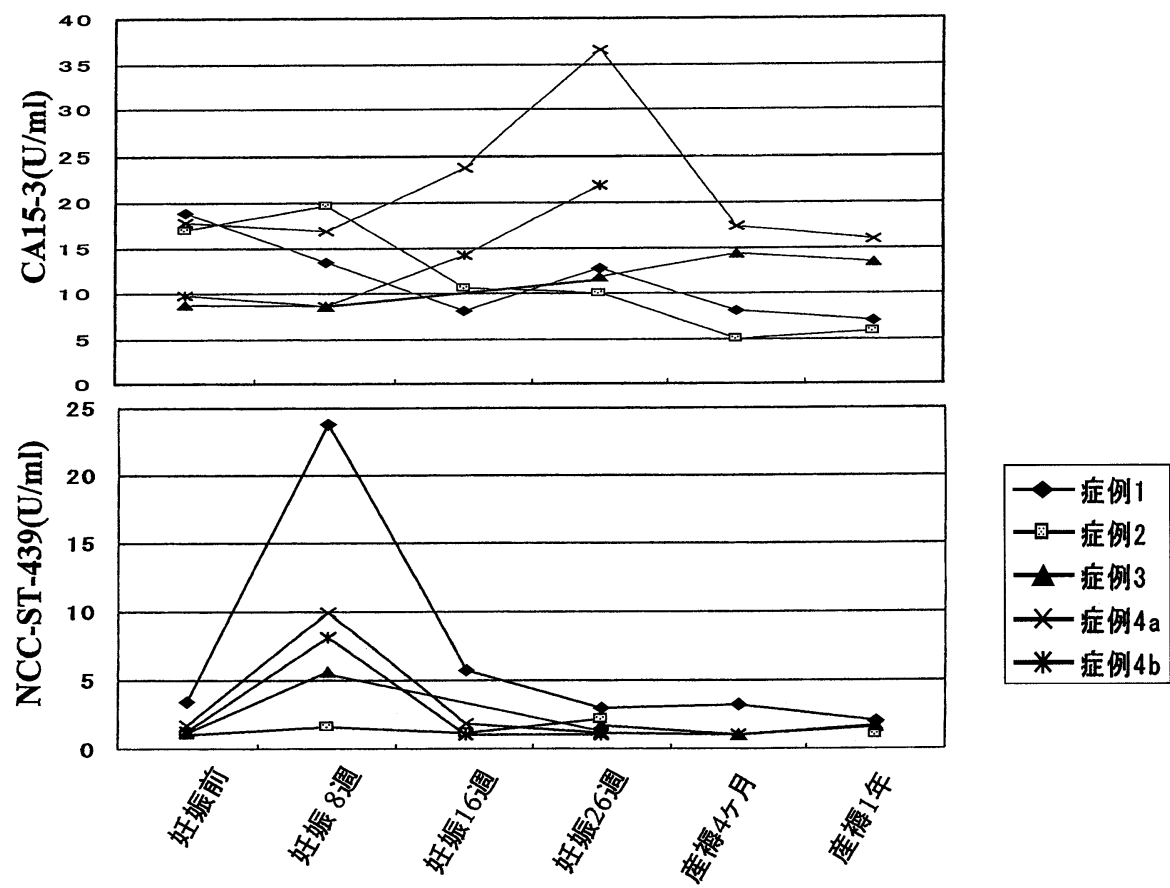

図 1. 各症例における腫瘍マーカーの推移 


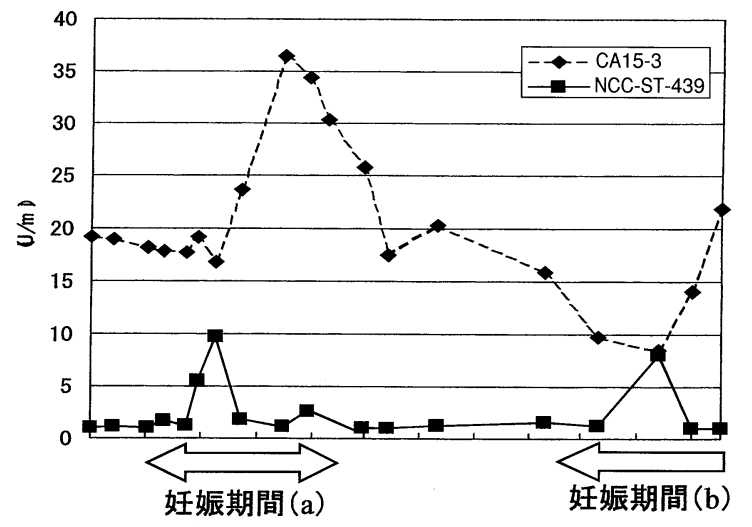

図 2. 症例 4 の腫瘍マーカー値

月 8 日を最終月経として妊娠し，2001年 8 月 7 日 正常分婏(男児， $3,025 \mathrm{~g}$ ) となった。産裖経過は 順調で 6 カ月間授乳した。

症例 3(40歳， 1 回経妊 1 回経産) : $2.5 \mathrm{~cm}$ の腫 瘤のため1996年 4 月胸筋温存乳房切除術を施行し た (T2 N0Ｍ 0)。1999年10月29日を最終月経とし て妊娠に至り，2000年 8 月10日正常分婏(男 児， $3,000 \mathrm{~g}$ )となった。産裖経過において特記す べきことはなかった。

症例 $4(27$ 歳, 0 回経妊 0 回経産) $: 1.8 \mathrm{~cm}$ の腫 瘤のため1997年12月乳房温存手術を施行した (T1 N0 M0)。術後放射線治療の後に 2 年間 5 -DFUR を投与した。2001年 7 月21日を最終月経として妊 娠に至り，2002年 4 月19日正常分娩(男児，2,422 g) となった。その後，2003年 7 月 27 日を最終月 経として 2 回目の妊娠に至り，2004年 3 月現在, 妊娠継続中である。

つぎに, 妊娠・産䙏期の各腫瘍マーカーの推移 を図 1 に示す。

症例 1 : CA15-3は大きな変動は認めず, NCC-ST -439 は妊娠初期に $23.8 \mathrm{U} / \mathrm{m} l$ と高值を示し, その 後基準值以下に低下した。

症例 $2: \mathrm{CA15}-3$ は妊娠初期に軽度上昇を認め, NCC-ST-439は妊娠・産裖期ともに変動しなかっ た。

症例 3 : CA15-3は妊娠全般にわたり軽度上昇を 認めたが, 産裖 1 年以内には低下し, 基準值以下

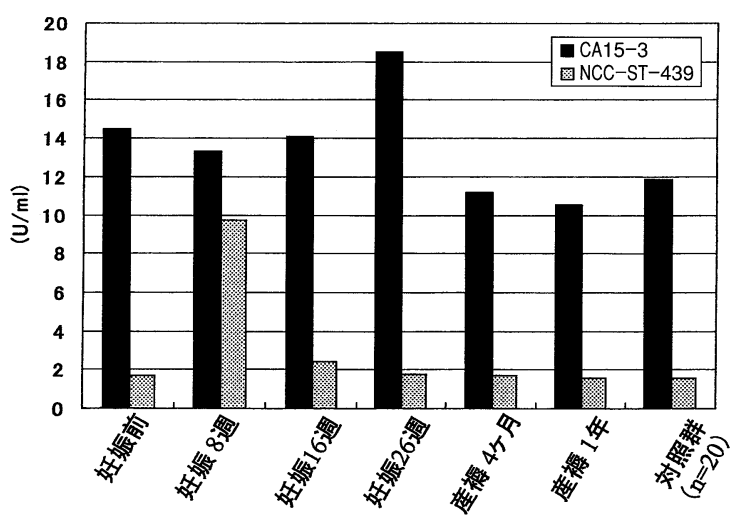

図 3. 妊娠・産裖期の腫瘍マーカーの平均值

となった。NCC-ST-439は妊娠初期に $5.5 \mathrm{U} / \mathrm{ml}$ と上昇するも妊娠後期〜産裖期に低下し，基準值 以下となった。

症例 $4(4 \mathrm{a}$ : 第 1 回目妊娠, $4 \mathrm{~b}$ : 第 2 回目妊 娠): 初回妊娠時 CA15-3は妊娠後期で軽度上昇 を認めたが産裖期には低下し，NCC-ST-439は妊 娠初期に $9.8 \mathrm{U} / \mathrm{m} l$ と上昇するも妊娠後期・産裖 期には低下した。 2 度目の妊娠は継続中である が，現時点では初回妊娠と同じ推移をたどってい る(図 2)。

さらに,この 4 症例 ( 5 妊娠期, 4 産裖期) の腫 瘍マーカー值を対照群と比較したところ(図 3), CA15-3は妊娠中期〜後期に上昇を認めた。NCCST-439は妊娠初期において一過性に上昇傾向を 示すも，いずれも産裖 4 力月には低下した。

\section{2. 考 察}

CA15-3は，母乳脂肪球の膜抗原と乳癌細胞膜 から抽出した 2 種のモノクローナル抗体と反応す るムチン抗原で, 血清の上皮細胞の表面に存在し ている ${ }^{6}$ 。早期・原発性乳癌の診断価值は低いが, 転移性乳癌の治療効果および再発の予知には重要 とされている5)。一方，NCC-ST-439は糖鎖関連 抗原であり，1984年に広橋らが胃低分化腺癌を免 疫原として作成したモノクローナル抗体 ST439に よって認識される抗原である7)。陽性率はあまり 高い頻度ではないが，健常人や良性乳腺疾患など 
の非癌患者には偽陽性率は低く, 診断効率で優 れ，乳癌に特異性の高い腫瘍マーカーであるとさ れている8)。

妊娠から産裖期にかけての同一例における連続 した腫瘍マーカーの測定報告は稀で，Demetrios $\mathrm{B} ら^{6)}$ は, CA15-3は妊娠後期のみ軽度上昇を認め るため, CA15-3は妊娠中の乳癌発見の指標にな ると述べている。また Hilkens ら ${ }^{9)}$ は，ヒト乳汁 の脂肪球膜上の糖蛋白を抗原と認識するため, 妊 娠後期には一過性にCA15-3が上昇するとしてい る。今回の症例検討では, CA15-3は妊娠中期か ら後期に非妊娠時の約 1.3 倍上昇したが，基準值 範囲内であり，産裖 4 ケ月で非妊娠時の值に戻っ た。彼らの考察からすると, 乳汁分泌が活発な産 裖期にも CA15-3は上昇するであろうと予測され たが，今回の症例検討からでは CA15-3は産裖期 にすでに非妊娠レベルまで低下を示した。したが って, 妊娠後期における CA15-3の一過性の上昇 は糖鎖抗原の増加以外の変化も関与することが推 測された。

NCC-ST-439の妊娠から産裖期にかけての変動 については，妊娠初期に非妊娠時の約 5.7 倍上昇 し，妊娠中期以降に非妊娠時の值に戻ることが観 察された。症例数が少ないため有意な上昇ではな かったが，菅野ら は，妊娠期間，特に初期にお いて NCC-ST-439は有意に高值を示すと述べて おり，今回の結果と矛盾しなかった。産裖期間中 の NCC-ST-439の変動については報告がなく, 今回の症例検討では産裖期は非妊娠時の值と同等 であった。産裖期については症例数が少数であっ たため, 今後引き続き症例数を増やして検討する 予定である。

また，今回繰り返して妊娠した症例 4 の推移か ら，妊娠という特殊な環境下で，妊娠性変化によ り腫瘍マーカーが変動することが推測された。

近年, 乳がん集団検診法の精度管理の向上や自 己検診法の啓発活動により，出産適龄期女性の乳 癌の発見が増加しつつある。すでに乳癌検診受診 率が60〜 70\%以上である欧米諸国においては ${ }^{10)}$, 乳癌患者の約 $15 \%$ が出産適龃期の女性である ${ }^{11}$ 。
このためわが国でも妊娠関連乳癌は増加すると予 想され, 今後, 妊婦・裖婦の乳がん検診は不可欠 であると思われる。しかし，妊婦・裖婦に対する 系統的乳がん検診法は現在確立されておらず，視

・触診法に超音波検査を併用する方法では妊娠性 変化による false positiveが多い。したがって， 乳がん検診法の一手段として腫瘍マーカー測定を 妊婦から裖婦に併用することも検討した方が良い と思われる。尚, 併用する際は, 上記の各腫瘍マ 一カー值の妊娠から産裖期間中の特徽的な変動を 念頭に置き，応用する必要があると思われた。

\section{結 語}

今回の検討では, CA15-3は妊娠中期〜後期に 一過性に上昇を認め，NCC-ST-439は妊娠初期に 一過性に上昇するも妊娠後期には基準值に下降す ることが確認された。いずれも産裖 4 ケ月以降は 非妊娠時の值に戻った。この経過から生理的妊娠 性変化によって腫瘍マーカーが变動したと想定さ れ，妊娠時期による腫痬マーカー選択の参考にな ると思われた。

\section{【文 献】}

1) Malamos NA, Stathopoulos GP, Keramopoulos A, et al: Pregnancy and offspring after the appearance of breast cancer. Oncology, 53 : 471475, 1996

2 ）土橋一慶, 赤川 元, 森田哲夫: 妊娠 - 産裖中 の乳房管理. 周産期医学, 34:371-374，2004

3 ) 赤川 元, 土橋一慶：妊娠初期における妊婦乳 房検診方法の検討. 日乳癌検診学会誌, $12: 193$ $-198,2003$

4 ）菅野康吉：ヒト胃癌株を抗原として作成された モノクローナル抗体 NCC-ST-439の癌血清診断 への応用に関する研究. 慶應医学, 66:553563, 1989

5 ) 古川郁子, 志保裕行, 星 直樹, 他: 化学発光 を用いた乳癌マーカーCA15-3 の基礎的検討と 臨床的有用性. 医学と薬学， $36 ： 817-828 ， 1996$

6 ) Botsis D, Sarandakou A, Kassanos D, et al : Breast cancer markers during normal pregnancy. Anticancer Res, $19: 3539-3542,1999$ 
7 ）鈴木眞一, 二瓶光博, 野水 整, 他：乳癌に打 ける糖鎖関連抗原 NCC-ST-439の検討.日癌 治, $25 ： 1019-1026,1990$

8 ）大倉久直，服部 信，宮崎逸夫，他：各種癌 · 良性疾患患者血清による NCC-ST-439 EIA キッ 卜の臨床的検討 (2). 癌と化療, $14: 1907-$ 1912, 1987

9 ) Hilkens J, Buijs F, Hilgers J, et al: Monoclonal antibodies against human milk-fat globule membranes detecting differentiation antigens of the mammary gland and its tumors. Int $\mathrm{J}$
Cancer, $34: 197-206,1984$

10) Weir HK, Thun MJ, Hankey BF, et al: Annual report to the nation on the status of cancer. 19752000 , featuring the uses of surveillance data for cancer prevention and control. J Nat Cancer Inst, 95:1276-1299, 2003

11) Deborah K : Breast Cancer : Gynecologic, reproductive, and hormonal issues. In Cancer Obstetrics and Gynecology, Maryland America, 1999, pp. 133-156

\title{
Effectiveness of Breast Cancer Screening during Pregnancy and Lactation Using Serum Tumor Markers : Study of Pregnant Women after Treatment for Primary Breast Cancer
}

\author{
Kuniko Mori $^{1)}$, Kazuyoshi Dobashi ${ }^{2,3)}$, Minoru Ueki ${ }^{1)}$, Kota Okinaga ${ }^{3)}$ \\ Department of Obstetrics and Gynecology ${ }^{11}$, Osaka Medical College Hospital \\ Senkawa OB/GYN and Breast Clinic ${ }^{2)}$ \\ Department of Surgery ${ }^{3)}$, Teikyo University School of Medicine
}

It is considered that pregnancy-associated breast cancer has the same prognosis as nonpregnancy-associated breast cancer at any given stage. In many cases, however, pregnancyassociated breast cancer is discovered at an advanced stage because of the lack of a systematic breast cancer screening method for pregnant women. We have reported that an appropriate breast cancer screening method during pregnancy involving a combination of palpation and ultrasonography is more effective than screening by palpation alone. However, because of gestational changes, the false positivity rate is high. Therefore, a more effective screening method during the period of gestation and lactation is needed. In this study, we investigated five pregnant women after treatment for primary breast cancer. We measured the serum levels of tumor markers such as CA15-3 and NCC-ST-439 before, during and after pregnancy. The level of CA15-3 was increased during the mid to late gestation period, and that of NCC-ST-439 was increased during early gestation. However, the levels of both CA15-3 and NCC-ST-439 returned to the normal range in the 4 months after parturition. Our findings suggest that it is necessary to measure the serum levels of tumor markers during pregnancy and lactation, while considering changes in the levels of CA15-3 and NCC-ST-439 according to gestational stage.

Key words : pregnancy-associated breast cancer, breast cancer screening method, serum tumor marker, CA15-3, NCC-ST-439 